Supporting Information

\title{
Protein Fibrils Induce Emulsion Stabilization
}

Jinfeng Peng, Joana Ralfas Simon, Paul Venema,* and Erik van der Linden

Laboratory of Physics and Physical Chemistry of Foods, Department of Agrotechnology and

Food Sciences, Wageningen University, P.O. Box 17, 6700 AA, Wageningen, The Netherlands

* Corresponding Author

Tel +31 317 485023; e-mail Paul.Venema@wur.nl (P.V.) 
Table S1. Volume fraction of fibrils as a function of WPI weight concentration.

\begin{tabular}{|c|c|}
\hline WPI concentration (wt \%) & Fibril volume fraction $(\varphi)$ \\
\hline 0.001 & $3.75 \times 10^{-6}$ \\
\hline 0.005 & $1.87 \times 10^{-5}$ \\
\hline 0.01 & $3.75 \times 10^{-5}$ \\
\hline 0.05 & $1.87 \times 10^{-4}$ \\
\hline 0.1 & $3.75 \times 10^{-4}$ \\
\hline 0.5 & $1.87 \times 10^{-3}$ \\
\hline 1 & $3.75 \times 10^{-3}$ \\
\hline 1.5 & $5.62 \times 10^{-3}$ \\
\hline 2 & $7.50 \times 10^{-3}$ \\
\hline 2.25 & $8.43 \times 10^{-3}$ \\
\hline 2.5 & $9.37 \times 10^{-3}$ \\
\hline 2.75 & $1.03 \times 10^{-2}$ \\
\hline 3 & $1.12 \times 10^{-2}$ \\
\hline 3.25 & $1.22 \times 10^{-2}$ \\
\hline 4 & $1.50 \times 10^{-2}$ \\
\hline
\end{tabular}



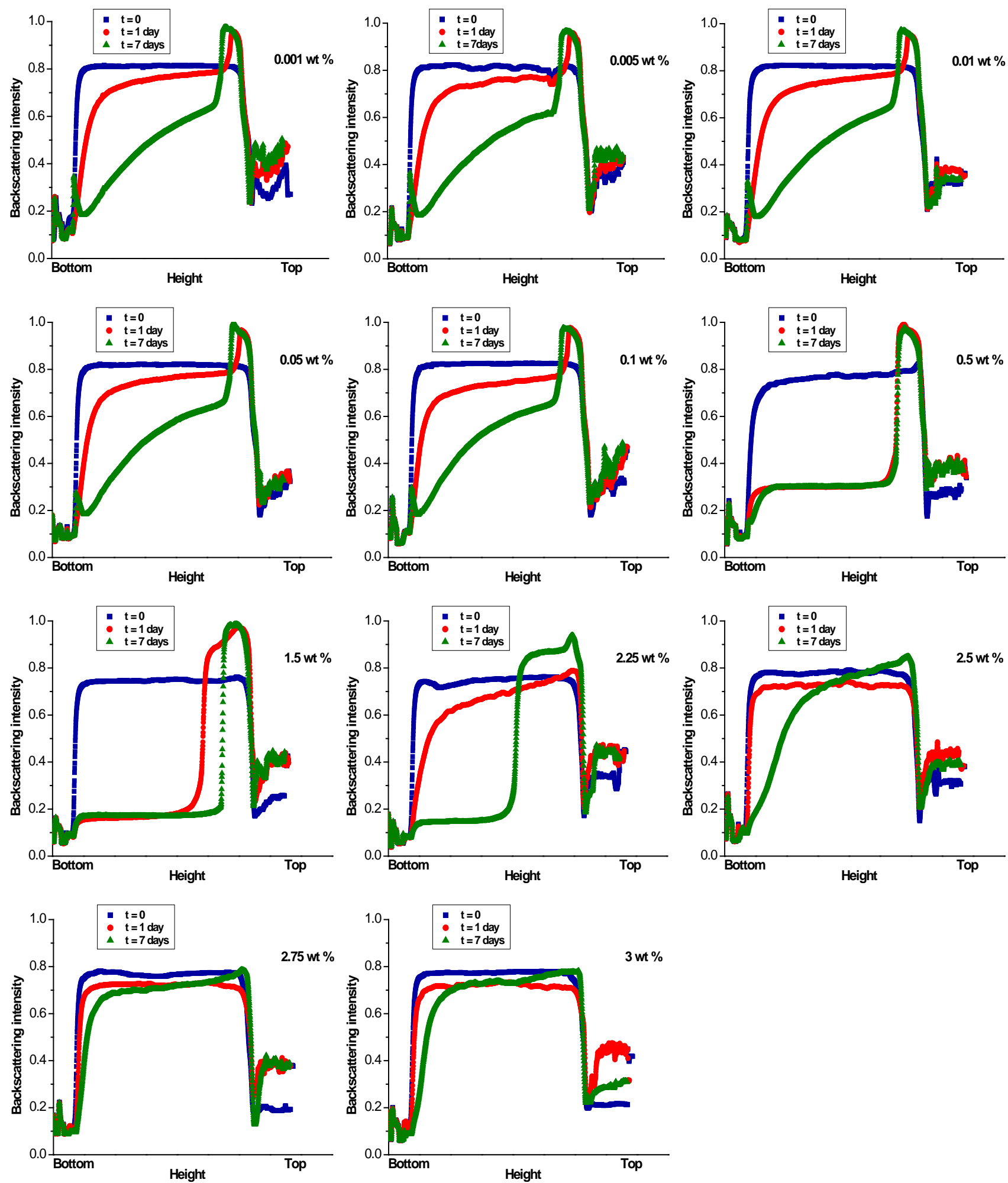

Figure S1. Backscattering intensity profiles of samples containing $10 \%(\mathrm{v} / \mathrm{v}) \mathrm{o} / \mathrm{w}$ emulsion and $0.001,0.005,0.01,0.05,0.1,0.5,1.5,2.25,2.5,2.75$ or 3 wt $\%$ protein fibrils. The horizontal axis represents the position along the tube. 